\title{
Appearances do matter! What libraries can learn from Clinton Kelly
}

$\mathbf{O}$ ne could easily mistake Clinton Kelly's closing keynote presentation at ACRL 2011 in Philadelphia last March as light fare. Kelly, cohost of TLC's What Not To Wear, spoke enthusiastically about the importance of one's appearance and the necessity of making an extra effort in the way individuals present themselves. His keynote address, and the fact that a fashion expert was a speaker at a conference for librarians, sparked debates on Twitter and in the blogosphere.

Do appearances matter? I say they do and add that this applies to buildings and objects, as well. Academic libraries, especially, could benefit from some of Kelly's advice. For too long, we have expected students to visit the library because they have to, without making an effort to make their experiences satisfying and productive. The Internet makes it possible to access resources and assistance without visiting in person; we need to work harder to give students a reason to come to the library. Outdated or inefficient signage, confusing wayfinding, and uncomfortable seating can make an in-person visit frustrating and unsatisfying. Here, some advice from Kelly and how we can apply them to libraries.

"What you wear tells the world how you expect to be treated."

Signage and wayfinding are simple and visible ways to communicate with patrons. What message are libraries sending when signage is hard to read, looks unprofessional, or is nonexistent? You do not need to be able to afford a graphic designer to create professional signage, although that would be the ideal solution. There are books, such as Graphic Design For Nondesigners by Tony Seddon and Jane Waterhouse, which can help neophyte designers choose a typeface and develop a layout. Well-chosen typography, concise and consistent design, and a message that is brief and to the point will send a clear and professional message to your patrons that they are in an academic library. It will also limit directional questions that can monopolize information desk staff. This does not mean the design and message has to be serious, but pay attention to the image that your signage and posters are projecting to your users. These nonverbal cues will differentiate an art and architecture library from a science and engineering library.

Not caring about your appearance is "telling the rest of the world-and yourself - that you don't really matter."

Sloppy signage, dirty computer screens, overflowing trashcans and recycling bins, and filthy bathrooms send the message to users that the library does not care enough about itself or its patrons to keep the building clean. Why expect patrons to respect a space, or furthermore, to return to it, when the library does not keep it clean?

Keeping space clutter-free is important, as well. Too much of anything is distracting, especially in entryways where patrons are in transition to a new space and are focused on finding their way. Take a cue from Kelly's course of actions on What Not To Wear and dump anything that is outdated, damaged, or no longer used into the trash. The popularity

Nancy Fawley is head of Gorgas Information Services at the University of Alabama Libraries, e-mail: nefawley@ ua.edu

(C) 2012 Nancy Fawley 
of home design shows has made consumers, including students, more knowledgeable about, and aware of, good design. A clean and uncluttered appearance sends a powerful message that the library is relevant by today's standards.

"When you take control of your message and of how you want to be perceived by otherpeople, it's empowering. "3

Creating a brand is a powerful and effective way to establish a predefined image of your library in the minds of its users. There are companies that specialize in creating visual identities for corporations, but there are simple steps a library can take to develop a targeted and consistent identity in its users' minds. Develop a logo or tagline that reflects the mission of the library and differentiates it from other resources within and outside the university. Use your library's logo in a manner that is consistent with its vision. A library tagline on a USB drive is logical, but a logo on a Frisbee can create a disconnect between the object and the library's brand. Create a style manual that clearly states the font, type size, and color that are to be used in all library materials so that everything, from class handouts to annual reports, visually represents the library in the same manner.

"Fabulousity is not just a way of life: it's a state being. . . . More than anything, you are fabulous if you treat people with respect and encourage them to develop their own fabulous qualities. ${ }^{\text {"t }}$

Great design, clear signage, and a focused identity can only do so much to make a library

("More than organic," cont. from page 407)

Brief Series no. SRB 99-02 (Beltsville, MD: National Agricultural Library), www.nal.usda. gov/afsic/pubs/terms/srb9902.shtml (accessed May 21, 2012).

2. G. Feenstra (n.d.), "What is Sustainable Agriculture?" (Davis, CA: Agricultural Sustainability Institute, UC Davis), www.sarep.ucdavis. edu/sarep/about/def (accessed May 21, 2012).

3. B. Butterfield (n.d.), "Garden Market Research" (South Burlington, VT: National user's visit satisfactory. If you are not providing timely and respectful service, none of the hard work you have done to improve your library's appearance will make a difference.

It is easy to dismiss concerns about appearances as frivolous, but we make decisions based on how something or someone looks on a daily basis. Does this street look safe to walk down? Does this salesperson look like she will be helpful? This restaurant looks filthy; should we eat here? Some decisions may be lifesaving; others may just enhance an experience.

Academic libraries provide an important service to their communities. Creating a safe and clean environment that is easy to navigate with well-designed spaces and clear and concise signage is something that can be done on a small or large budget. Paying attention to your library's appearance can go far to enhance a patron's experience.

\section{Notes}

1. Clinton Kelly, Freakin' Fabulous (New York: Simon Spotlight Entertainment, 2008), 3.

2. Devny Renner, "Clinton Kelly Interview," BlogHer: Life Well Said, 1 March 2011, www.blogher.com/tlcs-what-not -wear-ambushes-parenting-dummies-dc-and -clinton-kelly-agrees-his-first-social-media -int?page $=0,1$.

3. Erin Casey, "1-on-1: Confidence Never Goes Out of Fashion," Success Magazine, 2011, www.successmagazine.com/1on1 -clinton-kelly/PARAMS/article/1407 /channel/22.

4. Kelly, 239. n

Gardening Association, www.gardenresearch. com/home?q=show\&id=2896, (accessed May 21, 2012).

4. "Industry Statistics and Projected Growth,” (2011) (Battleboro, VT: Organic Trade Association) www.ota.com/organic /mt/business.html (accessed May 21, 2012).

5. "Questions and Answers-Graduate Program in Sustainable Agriculture" (2010). (Ames, IA: Iowa State University, www.sust. ag.iastate.edu/gpsa/qanda.html (accessed May 21, 2012). $\boldsymbol{n}$ 